\title{
GIMNAZIJSKO UČENIČKO DRUŠTVO SVAČIĆ
}

Učeničko društvo Svačić počelo je djelovati 1906. godine kao tamburaški zbor unutar varaždinske Gimnazije, a ubrzo je kao organizirano tamburaško društvo nastupalo i izvan škole. Pod vodstvom prof. Milana Stahuljaka oblikovani su kvalitetan tamburaški i pjevački zbor te salonski orkestar koji su do ljeta 1913. godine, priređivali glazbeno-deklamatorne produkcije povremeno dopunjavane amaterskim predstavama i organiziranim plesom. Bez Svačićevog sudjelovanja ubrzo je postala nezamisliva svaka ozbiljnija priredba u Gimnaziji, a njegovi programi znatno su obogatili kulturnu i zabavnu ponudu u gradu. Pred Prvi svj. rat ulogu Svačićevog zborovođe preuzeo je prof. Tomislav Miškulin pod čijim je vodstvom ova djelatnost nadopunjena izuzetno kvalitetnim koncertnim aktivnostima. Čim su to političke okolnosti dopustile, Svačićevi su nastupi, tijekom i nakon rata, pomogli prikupljanju novca za pomoć siromašnim gimnazijalcima i ratnim stradalnicima.

Zalaganjem Milana Kamana, novog ravnatelja varaždinske Gimnazije, diktatorski režim kralja Aleksandra je 1930. ipak dozvolio osnivanje Varaždinskog gimnazijskog udruženja „Svačić“ s ciljem da lakše kontrolira izvannastavne aktivnosti u školi. Rad udruženja propisan je Pravilima potvrđenim od Ministarstva prosvjete i organiziran je kroz sekcije. $U$ početku su utemeljene glazbena, znanstvena i literarna, a sljedećih godina oformljene su sportska, likovna šahovska i filatelistička sekcija. Nastavni savjet imenovao je profesore voditelje sekcija koje su održavale radne sastanke pripremajući programe za tzv. sijela, priredbe putem kojih su svoj rad predstavljale unutar škole ili na nivou grada, a povremeno su Gimnaziju predstavljale i na višim razinama. Pritom se posebno isticala sportska sekcija pod vodstvom prof. Zvonimira Suligoja koja se, uz lokalne manifestacije predstavljala na državnim sletovima. Glazbena sekcija pod vodstvom prof. Tomislava Miškulina je svoje koncertne programe predstavljala u Hrvatskom glazbenom zavodu i zagrebačkoj katedrali. Literarna sekcija je učeničke radove povremeno objavljivala u zagrebačkim književnim revijama, a samostalno je izdavala učenički list Svačić. Zahvaljujući njihovoj aktivnosti kulturni, zabavni i društveni život u Gimnaziji i Varaždinu 30-ih godina 20. stoljeća bio je znatno bogatiji i kvalitetniji. No promjenom političkih odnosa neposredno pred Drugi svjetski rat, rad ove udruge bio je ugašen.

Ključne riječi: Učenička društva; Gimnazija Varaždin; pjevački zbor; tamburaški zbor; Varaždin. 


\section{UVOD}

Početkom 20. st. na području Banske Hrvatske došlo je do postupnog oslobađanja od pritiska represivnog Khuenovog režima. Burni nacionalni pokret 1903. prvo je doveo do njegovog napuštanja banskog položaja, a njegova Narodna stranka poražena je na izborima 1906. godine. Ove promjene odrazile su se i na županijskoj razini pa je u Varaždinskoj županiji, veliki župan Radoslav Rubido Zichy nakon 20 godina, također morao napustiti svoj položaj.

Spomenute promjene varaždinska je Gimnazija dočekala kao gimnazija klasičnog tipa. Nakon što je 1899. godine, umro izuzetno poštivani ravnatelj, Franjo Pongračić, uslijedile su česte promjene ravnatelja od kojih su neki samo kratko ostajali na dužnosti. U profesorskom zboru se baš u ovom razdoblju odvijala postupna smjena generacija, a novonastala sloboda djelovanja potakla je sve veću živost među gimnazijalcima koji su se počeli uključivati u kulturne i političke aktivnosti, sudjelujući u osnivanju i radu novih udruga. Kao jedna od novo osnovanih udruga 1906. godine ${ }^{1}$ osnovan je tamburaški zbor koji je ubrzo prerastao u Gimnazijsko tamburaško društvo Svačić. Ono je sljedeće godine nastupalo u Gimnaziji, a ubrzo i izvan nje. ${ }^{2}$ U Hrvatskom pravu navedeno je kako je 7. lipnja 1908., gimnazijsko društvo Svačić, sa Gospojinskim odborom i djevojačkom školom, za potrebe školske djece priredilo koncert u gradskoj gombaoni. U programu je, uz tamburaše, sudjelovao i pjevački zbor, izvodeći skladbe domaćih i slovenskih autora te narodnu glazbu. ${ }^{3}$ Tako je počelo djelovati Gimnazijsko učeničko društvo Svačić koje je u slijedećih 35 godina predstavljalo bitan čimbenik u oblikovanju glazbene i scenske aktivnosti u Gimnaziji, a u razdoblju diktature okupilo je većinu učeničkih slobodnih aktivnosti. Pritom je značajno pridonijelo kulturno-zabavnom životu u Varaždinu.

\section{PREDRATNO RAZDOBLJE}

Društvo je u prvim godinama djelovalo pod vodstvom prof. Milana Stahuljaka, koji je u njegovom sastavu organizirao kvalitetan pjevački i tamburaški zbor, a nešto kasnije oformljen je i Svačićev salonski orkestar koji je, uz umjetnički dio programa, ${ }^{4}$ pridonosio zabavi i plesovima povremeno organiziranim nakon služ

1 Koncert gimnazijskog tamburaškog društva „Svačić", Hrvatske pravice br. 8 od 20. veljače 1909., str. 5.

2 Krešimir FILIĆ: "Povijest varaždinske gimnazije', Spomenica varaždinske gimnazije 1636.-1936., Varaždin 1937., str. 110.

3 Koncert gimnazijalaca, Hrvatske pravice br. 24 od 13. lipnja 1908., str. 4.

4 Profesor Stahuljak je, uz redovite nastavne predmete, predavao i pjevanje kao neobligatni predmet. 
benih nastupa. Uz suradnju profesora hrvatskog jezika okupljane su učeničke glumačke družine, pa su povremeno priređivani programi koji su, uz koncerte obuhvaćali i diletantske dramske predstave. Već 16 . veljače 1909. pod nadzorom profesorskog zbora u gradskom kazalištu je priređena glazbena produkcija s kajkavskom komedijom Barun Tamburlanović, nakon čega je u kazališnoj restauraciji organizirana plesna zabava. ${ }^{5}$ Dok je za realizaciju glazbenog dijela programa zasluga pripadala prof. Stahuljaku, predstava je pripremljena pod nadzorom prof. Luke Goloba. ${ }^{6}$ Kako je za njihove programe i u širim građanskim slojevima vladalo veliko zanimanje, oni su često ponavljani jer bi u protivnom mnogi ostajali bez mjesta. I ovom prilikom je društvo potaknuto zanimanjem slušateljstva, odlučilo ponoviti koncert u ponedjeljak 22. veljače. Potkraj spomenute školske godine, točnije 12. lipnja 1909. gimnazijsko učeničko društvo Svačić priredilo je u dvorani gradskog kazališta, još jednu glazbeno deklamatornu produkciju.

Svačić je za gimnazijalce redovito priređivao priredbe internog karaktera, koje su obično održavane u prostoru gimnazijske risaone, tada najveće prostorije u školi. Takva priredba priređena je 29. svibnja 1910., a uz bogat glazbeni program, obuhvatila je i stručno predavanje prof. Stahuljaka na temu Osobine hrvatske pučke i starogrčke glazbe. Javnost je ovakav rad od početka zdušno podržavala pa su pretplate za njihove nastupe često uplaćivale mnoge istaknute osobe iz varaždinskog društvenog i kulturnog života. ${ }^{9}$ Kritika ih je redovito pratila i često pozitivno komentirala. ${ }^{10}$ Kako su njihovi programi uglavnom bili humanitarnog karaktera, gradske vlasti su im besplatno ustupale prostor kazališta. Tako iz tiska saznajemo da se: Gimnazijalnom tamburaškom družtvu "Svaćić" ustupa (...) besplatno uporaba gradskoga kazališta za 22. i 26. veljače uz uvjet, da od bruto-dohotka druge glazbene produkcije imade dati $10 \%$ za gradske siromake. ${ }^{11}$

U spomenuto vrijeme Gimnazijsko tamburaško društvo Svačić je u kazalištu priredilo glazbenu produkciju, a među točkama programa našla se i predstava Matijaš Grabancijaš dijak. ${ }^{12}$ Prihod zabave namijenjen je podupiranju siromašnih gimnazijalaca. U programu su, uz pohvale kritike, nastupili tamburaški i mješo-

Naše pravice br. 7 od 18. veljače 1909., str. 6.

6 Koncert gimnazijskog tamburaškog društva "Svačić“, Hrvatske pravice br. 8 od 20. veljače 1909., str. 5.

7 Koncert gimnazijskog tamburaškog društva „Svačić“, Hrvatske pravice br. 24 od 12. lipnja 1909., str. 5.

$8 \quad$ Izvješće kr. velike gimnazije u Varaždinu za školsku godinu 1909.-10., str. 47.

9 Preplate prigodom koncerta gimn. tamb. društva "Svačić", Naše pravice br. 10 od 11. ožujak 1909., str. 6.

10 Naše pravice br. 8 od 25. veljača 1909., str. 5.

11 Naše pravice br. 9 od 2. ožujka 1911., str. 4.

12 Izvještaj kr. velike gimnazije u Varaždinu za školsku godinu 1910./11., str. 10. 
viti zbor i salonski orkestar pod ravnanjem prof. Stahuljaka te glumačka družina, uz režiju prof. Goloba. ${ }^{13} \mathrm{Na}$ traženje slušateljstva i ovaj program bio je ponovljen. ${ }^{14}$

Kraj 1910./11. godine obilježen je 30. lipnja, priredbom otvorenom za javnost u gradskoj gombaoni, uz deklamacije i glazbeni program u izvedbi Svačićevih zborova i njegovog salonskog orkestra. ${ }^{15}$ Slični programi, koji su pred Prvi svjetski rat sve češće bili dobrotvornog karaktera, priređivani su i ubuduće. Uz odobrenje ravnateljstva, 6 . veljače 1912 . Svačić je priredio internu glazbenu produkciju kojom je za potrebe gimnazijskog potpornog društva prikupljen prihod u iznosu od $50 \mathrm{Kr}^{16}$

U subotu 15. lipnja 1912., Svačić je u prostoru kazališta u korist istog društva priredio ljetnu zabavu čiji je prihod dijelom bio namijenjen za potrebe siromašnih gimnazijalaca. Program je, uz pjevačke i tamburaške točke, obuhvatio i originalnu satiru pisanu kajkavštinom Nije vsaki cipeliš na vsaku nogu ${ }^{17}$ Isto tako je 19. travnja 1913. u kazališnom prostoru organiziran Svaćićev koncert s plesnim vjenčićem. ${ }^{18}$ Ostvareni prihod je dijelom namijenjen gimnazijskom potpornom društvu, a iznos od 100 Kr. uložen je u učeničku putnu blagajnu, na čijem je osnutku neposredno pred rat intenzivno radio novi ravnatelj Vjekoslav Pacher. ${ }^{19}$ Sličnu priredbu je tamburaško društvo Svačić priredilo i 10. siječnja 1914., ${ }^{20}$ a u izvođenju pojedinih točaka sudjelovali su njegov mješoviti zbor i tamburaški orkestar. Pojedine skladbe izveli su solisti na violini i glasoviru. ${ }^{21}$ No dobrotvorni koncert bio je dopunjen igrokazom o barunu Tamburlanoviću, nakon čega je u kazališnoj restauraciji uslijedio ples, a prihod su podijelili gimnazijsko potporno društvo i učenička putna blagajna. ${ }^{22}$

Gimnazijsko tamburaško društvo Svačić svojim je programima predstavljalo okosnicu gimnazijskih školskih svečanosti i prigodnih obilježavanja blagdana. Brojnim dobrotvornim, javnosti namijenjenim priredbama, pridonijelo je kulturno-zabavnom životu Varaždina, a zahvaljujući neospornoj kvaliteti njihovih programa, bili su pozivani da daju svoj prilog gradskim manifestacijama poput velike pučke svečanosti priređene 9. srpnja 1911. u prostoru Sokolane, gdje su

\footnotetext{
Hrvatske pravice br. 7 od 18. veljače 1911., str. 4.

Hrvatske pravice br. 8 od 25. veljače 1911., str. 5.

Hrvatske pravice br. 25 od 24. lipnja 1911., str. 4.

Izvještaj kr. velike gimnazije u Varaždinu za školsku godinu 1911.- 12., str. 86.

"Nije vsaki cipeliš na vsaku nogu", Naše pravice br. 23 od 5. lipnja 1912., str. 3.

Naše pravice br. 16 od 10. IV. 1913., str.5.

Izvještaj kr. velike gimnazije u Varaždinu za školsku godinu 1912.- 13., str. 76.

Naše pravice br. 2 od 8. I. 1914., str. 5.

1 Raspored koncerta gimnazijskog tamburaškog društva "Svačić“, 10. siječnja 1914., GNV-KPO 5800.

22 Izvještaj kr. velike gimnazije u Varaždinu za školsku godinu 1913.- 14., str. 89-90.
} 
sudjelovala pjevačka društva Vila i Vijenac te tamburaški zbor Katoličkog djetićkog društva.

Gimnazijsko tamburaško društvo Svačić svojim je programima predstavljalo okosnicu gimnazijskih školskih svečanosti i prigodnih obilježavanja blagdana. Brojnim dobrotvornim, javnosti namijenjenim priredbama, pridonijelo je kulturno-zabavnom životu Varaždina, a zahvaljujući neospornoj kvaliteti njihovih programa, bili su pozivani da daju svoj prilog gradskim manifestacijama poput velike pučke svečanosti priređene 9. srpnja 1911. u prostoru Sokolane, gdje su uz društvo Svačić sudjelovala pjevačka društva Vila i Vijenac te tamburaški zbor Katoličkog djetićkog društva.

Uspjeh koncerata i glazbenih produkcija učeničkog društva Svačić u ovom je razdoblju ovisio o stručnosti i umješnosti prof. Stahuljaka, koji je i sam bio dobar violinist, orguljaš u gimnazijskoj crkvi i odličan poznavatelj tamburaških glazbala, sposoban dirigent, i skladatelj. Stoga ne treba čuditi da je Svačićev tamburaški orkestar doveo na zavidnu razinu, što mu je često priznavala i kritika. "Naše pravice su isticale kako: je mladež velikom ljubavlju i marom naučio ljubiti i razumijevati glazbu.."24 Pritom su pohvale često upućivane i voditelju i članstvu, pa je jednom prilikom navedeno: "(...) imadosmo prilike ćuti koncert naše nadobudne mladeži u velikoj dvorani gradskog kazališta. Svih nas se ugodno dojmilo gledati ovu uzdanicu našu i slušati kako svaki pojedini nastoji, da svoju zadaću što bolje i točnije, te sa najvećim oduševljenjem izvede. Svi su bili na mjestu, a njihov vodja i dirigent vrlo zaslužni g. prof. M. Stahuljak može se s njima ponositi i sa uspjehom koncerta zadovoljan biti., ${ }^{25}$ Kao vrstan stručnjak, objavljivao je stručne radove s područja muzikologije pa je u skladu s vladinom naredbom u gimnazijskom Izvješću za 1910./11., nakon 20-ak godina neobjavljivanja, ponovo objavljen stručni rad njenog profesora. Bio je to tekst Stahuljakovog predavanja na temu "Osobine hrvatske pučke i starogrčke glazbe", održanog u okviru Svačićeve priredbe 29. svibnja 1910. godine. ${ }^{26}$

\footnotetext{
Hrvatske pravice br. 26 od 1. srpnja 1911., str. 3.

Koncert "Svačića", Naše pravice br. 18 od 24. travnja 1913., str. 3.

Koncert gimnazij. tamburaškog društva Svačić, Naše pravice br. 19 od 1. svibnja 1913., str. 4. Izvješće kr. velike gimnazije u Varaždinu za školsku godinu 1909.-10., str. 47.
} 
No, krajem 1912./13. godine, odlukom Odjela za bogoštovlje i nastavu vlade u Zagrebu od 21. srpnja 1913. prof. Stahuljak dobio je službe radi, premještaj u zagrebačku donjogradsku gimnaziju, ${ }^{27}$ pa se aktualiziralo pitanje njegovog dosljednog nasljednika na položaju orguljaša u gimnazijskoj crkvi, učitelja pjevanja i voditelja tamburaškog društva Svačić. Na njegovo mjesto je odlukom istog Odjela 19. rujna 1913., postavljen kandidat srednjoškolskog učiteljstva, Tomislav Miškulin, angažiran za podučavanje u crkvenom i svjetovnom pjevanju. Svačićevi programi priređeni u posljednjoj predratnoj godini bili su pripremljeni i izvedeni pod njegovim vodstvom. Posebno se to odnosilo na glazbeni program izveden 12. svibnja 1914., kad je Varaždin i Gimnaziju posjetio ban Skerlec. ${ }^{28}$ Tamburaški i pjevački zbor svojim sudjelovanjem uveličali su svečanost posvete novog gimnazijskog barjaka. Tijekom svog posjeta Varaždinu 16. i 17. svibnja 1914., posvetio ga je nekadašnji učenik ove škole, nadbiskup Antun Bauer koji ga je dao izraditi kao poklon bivšoj školi. Navečer 16. svibnja gimnazijalci su pred župnim stanom nadbiskupu otpjevali podoknicu, dok je sljedećeg dana u 8 sati u gimnazijskoj crkvi uslijedila pjevana latinska misa. U 10 sati uslijedila je svečana matineja u velikoj dvorani gradskog kazališta u čijem programu su, uz ostale, sudjelovali Svačićev pjevački i tamburaški zbor. ${ }^{29}$ Svečanosti su prisustvovali odličnici županije i grada, bivši profesori, mladež i građanstvo.

Izbijanjem Prvog svjetskog rata u Habsburškoj monarhiji bilo je uvedeno izvanredno stanje kojim je onemogućen politički život, a civilni život je podvrgnut potrebama vojske. Banskom naredbom od 27. srpnja 1914. obustavljeno je djelovanje svih društava i korporacija pa je zemaljska vlada morala zabraniti rad učeničkih udruga osim udruženja skauta. ${ }^{30}$ Već spominjani ravnatelj, Vjekoslav Pacher koji je općenito bio sklon podupiranju učeničke aktivnosti, nastojao je aktivirati gimnazijsko učeničko društvo Svačić i iz humanitarnih razloga. Uvjeti su to omogućili tek nakon što je smrću cara Franje Josipa, novi vladar, car Karlo dozvolio liberalizaciju liberalizaciju političkog i društvenog života u Monarhiji. No i prije nego su to nove prilike omogućile, ovo je društvo tijekom ratnih godina nastavilo organizirati koncerte s plesom za prikupljanje dobrotvornih priloga kako je to bilo provođeno i u predratnom razdoblju. Njihov je prihod najčešće bio namijenjen zbrinjavanju rat-

\footnotetext{
27 Izvještaj kr. velike gimnazije u Varaždinu za školsku godinu 1913.- 14., str. 3.

28 Isto, str. 90 - 91.

29 Naše pravice br. 21 od 21. V. 1914., str. 3.

30 "'Otpis br. 32742.", Izvještaj kr. velike gimnazije u Varaždinu za školsku godinu 1914.- 1915. str. 81.
} 
nih stradalnika, a tadašnji tisak je to pratio, podupirao i najavljivao. Hrvatsko pravo je primjerice pred Svačićev koncert pripreman za sredinu veljače 1916. objavilo: "Učenici kr. velike gimnazije u Varaždinu priredjuju u dobrotvorne svrhe početkom budućeg mjeseca koncert na kojem ćemo imati sgode da se osvjedočimo da je naša mladež uzprkos težkih vremena te svojih nauka prionula uz glazbu i pjevanje kojom kani olahkotiti sirotinji biedu. Veselimo se da ćemo slušati naše mladenačke pregaoce te već sada na taj koncerat naše rodoljubno gradjanstvo upozorujemo." ${ }^{31}$

Spomenuti koncert priređen je 17. veljače 1916., pod pokroviteljstvom kr. povjerenika Stjepana Beloševića u prostoru gradskog kazališta, a njegov prihod u iznosu od 777 Kr. namijenjen je zakladi za invalide, udovice i siročad poginulih ratnika Županije varaždinske. ${ }^{32}$ Pripremljeni program obuhvaćao je narodne popijevke u izvedbi Svačićevog mješovitog, muškog i tamburaškog zbora. ${ }^{33}$ Odjel za bogoštovlje i nastavu zemaljske vlade u Zagrebu tom je prilikom ravnatelju, profesorskom zboru i učenicima odao posebno priznanje za požrtvovnost, a kritika je vrlo povoljno ocijenila humanitarnu svrhu, financijski učinak i kvalitetu izvedenog programa. ${ }^{34}$ Desetak dana kasnije, 26. veljače 1916., Svačićev tamburaški zbor je u organizaciji ivanečke mladeži u svratištu Ivančica priredio koncert u korist slijepih vojnika. Uz dobro pripremljene glazbene točke u programu je, prema tradiciji iz predratnog razdoblja, izveden i igrokaz u jednom činu Prva kiša od F. Z. Milera.

Želeći pomoći invalidima, siročadi i udovicama nastradalih vojnika varaždinske županije, gimnazijalci su priredili i koncert koji je 16. veljače 1917. održan u gradskom kazalištu. ${ }^{36}$ Želeći pomoći invalidima, siročadi i udovicama nastradalih vojnika varaždinske županije, gimnazijalci su priredili i koncert koji je 16. veljače 1917. održan u gradskom kazalištu. Program je obuhvaćao izuzetno kvalitetne vokalne i instrumentalne skladbe na violini i glasoviru ili u izvedbi tamburaškog, dječačkog i muškog zbora. ${ }^{37}$ Zanimanje slušateljstva bilo je izuzetno veliko te je gledalište bilo ispunjeno, a pritom je ostvaren prihod u iznosu od $900 \mathrm{Kr}^{38}$ Prigodom dobrotvornog koncerta koji su 26. travnja 1917. učenici varaždinske Gimnazije priredili u priredili u korist ratne siročadi, bilo je organizirano prikupljanje sredstava prima-

\footnotetext{
Hrvatsko pravo, br. 3 od 15. siječnja 1916,. str. 3.

Hrvatsko pravo, br. 7 od 12. veljače 1916., str. 3.

"Izvještaj kr. Velike gimnazije u Varaždinu za školsku godinu 1913.- 14.", Učiteljski zbor, str. 10.

"Izvještaj kr. velike gimnazije u Varaždinu za školsku godinu 1915.- 1916.", Ljetopis, str. 79.

Hrvatsko pravo, br. 8 od 19. II. 1916., str. 2-3.

Hrvatsko pravo, br. 7 od 17. II. 1917., str. 4.

Hrvatsko pravo, br. 8 od 24. II. 1917., str. 5.

"Izvještaj kr. velike gimnazije u Varaždinu za školsku godinu 1916. - 1917.", Ljetopis, str. 32.
} 
njem pretplata. $U$ takvim su prilikama obično bogatije i uglednije osobe iz javnog života kao pretplatu izdvajale određene novčane iznose. ${ }^{39} \mathrm{U}$ prvim poratnim godinama ovakva je praksa bila nastavljena, uz prilagodbu novonastalim okolnostima.

\section{PORATNO RAZDOBLJE}

Po završetku Prvog svjetskog rata, novonastala Kraljevina SHS, nakon teritorijalnog ujedinjenja, usprkos pokušajima, čitavo desetljeće nije donijela sustavne zakonske odredbe kojima bi se odgojno-obrazovna i kulturna djelatnost na jedinstven način regulirala na prostoru nove države. Stoga je na tim područjima prevladavala neujednačenost, a obrazovne institucije i dalje su djelovale prema zakonima koji su u pojedinim krajevima bili na snazi i prije proglašenja Kraljevine U sličnim okolnostima su u prvom poratnom desetljeću djelovala i učenička društva. Kako bi što lakše moglo nastaviti djelovanje, Gimnazijsko tamburaško i pjevačko društvo Svačić nastojalo je svoju materijalnu osnovu osigurati širenjem mreže članova utemeljitelja i podupiratelja koji su svojim prilozima pomagali njegov $\operatorname{rad}^{40} \mathrm{Uz}$ ustanove i poduzeća, najčešće su to bili imućniji i ugledni članovi zajednice poput županijskih i gradskih dužnosnika, poduzetnika, liječnika i profesora. Početkom ovog razdoblja, najmanji utemeljiteljni prinos iznosio je $50 \mathrm{Kr}$. jednokratno, a podupirući članovi uplaćivali su najmanje $12 \mathrm{Kr}$. godišnje. ${ }^{41} \mathrm{Prva}$ poratna, a 13. po redu Glavna skupština društva sazvana je u nedjelju 21. rujna 1919. godine. Održana je na II. katu Gimnazije u sobi I. razreda, a uz podnesene izvještaje i razrješavanje starog vodstva izabrani su novi predsjednik, upravni odbor, zamjenici i novi revizionalni odbor. ${ }^{42}$

Kao i ranije, nakon Prvog svjetskog rata ovo je društvo kao svoju glavnu djelatnost, nastavilo njegovati glazbene aktivnosti kojima su kroz rad tamburaškog i pjevačkog zbora, razvijane ljubav prema glazbi i vještine u njenoj interpretaciji.

Zahvaljujući umijeću svojeg članstva, Svačić je neminovno postajao sudionik u svim ključnim manifestacijama koje su se u varaždinskoj Gimnaziji priređivale po-

\footnotetext{
${ }^{39}$ Tom prilikom je gradonačelnik, dr. Pero Magdić izdvojio 30, župan Stjepan pl. Belošević 20, a dr. Hinko Blau $10 \mathrm{Kr}$.

${ }^{40}$ Koncert društva Svačić, Volja naroda br.11 od 13. ožujka 1919. str. 3.

${ }^{41}$ Volja naroda br.31 od 31. srpnja 1919. str. 3.

${ }^{42}$ Slobodni građanin br. 26 od 20. rujna 1919., str. 3.
} 
vodom obilježavanja značajnih obljetnica, proslavljanja važnih datuma i uveličavanja ključnih događanja. Osim politički nužnih i nametnutih datuma u ovoj su ustanovi redovito obilježavani 30. travnja kao uspomena na pogibiju Petra Zrinskog i Frana Krste Frankopana, prekid državnopravnih odnosa s Austro-ugarskom 29. listopada te obljetnice čuvenih osoba iz svjetske i hrvatske prošlosti i kulture. U takvim prilikama priređivana su prigodna predavanja i svečane akademije s programom koji su izvodile učeničke udruge predvođene profesorima zaduženim za njihov rad. Glazbeni dijelovi takvih programa prirodno su postajali obveza Gimnazijskog tamburaškog društva Svačić i njegovog zborovođe. Tako je primjerice već 30. travnja 1920. u spomen na Zrinskog i Frankopana, nakon mise zadušnice u gradskoj gombaoni bilo priređeno prigodno izlaganje profesora povijesti Dragutina Marića popraćeno deklamacijama, a pjevačke i tamburaške točke programa izveli su članovi Svačića. ${ }^{43}$ Obljetnica njihove pogibije i ubuduće je redovito obilježavana, a osim u Gimnaziji, Svačić je svojim nastupima sudjelovao i u priredbama koje su pojedine udruge organizirale na nivou grada i županije. U organizaciji Hrvatskog društva Napredak, 1923. godine, je u počast hrvatskim mučenicima Petru grofu Zrinskomu i Krstu knezu Frankopanu u gradskom kazalištu priređena komemoracija. Tom prilikom učenici su gledateljstvu predstavili slike iz drame Higina Dragošića Posljednji Zrinski. Između činova bratska pjevačka društva: Svačić, Tomislav i Vijenac otpjevala su dvije pjesme, Frankopanska i Hrvatskoj. ${ }^{44}$

U organizaciji gimnazijske ekstenze 4. veljače 1923., priređena je proslava godišnjice rođenja narodnog dobrotvora, biskupa Strossmayera čiji je rođendan, također bio redovito obilježavan. ${ }^{45}$ Kako bi mu se odužili i odali počast njegovom kulturno-prosvjetnom radu u gimnazijskoj risaoni bila je priređena akademija kojoj su prisustvovale udruge, predstavnici vlasti i brojno građanstvo. Program je započeo Svačićev mješoviti zbor izvedbom Runjanin-Krajanskijeve skladbe Ljubimo te naša diko. Uslijedila je deklamacija Preradovićeve ode Strossmayeru, a nakon prigodnog izlaganja prof. Filića na temu Kulturno značenje biskupa Strossmayera, deklamirana je Aškerčeva V kripti djakovačke katedrale. Četiri mjeseca kasnije gimnazijski Ferijalni savez u dvorištu gombaone priredio je Gimnastičku akademiju. U prekidima između vježbi, prisutne je svojim izvedbama uveseljavalo gimnazijsko društvo Svačić. ${ }^{46}$

\footnotetext{
43 “Izvještaj kr. velike gimnazije u Varaždinu za školsku godinu 1919. - 1920.", Ljetopis, str. 15.

44 „Napredak“ u počast hrvatskim mučenicima, Narodno jedinstvo br. 17 od 28. travnja 1923., str. 3.

45 Narodno jedinstvo br. 6 od 10. veljače 1023., str. 4.

46 "Ferijalni savez", Narodno jedinstvo br. 22 od 2. lipnja 1023., str. 4.
} 
Svačićeva koncertna aktivnost u poratnom periodu započela je ubrzo po završetku ratnih djelovanja. Već 22. veljače 1919. priređen je koncert popraćen Programom s ilustracijom tamburaša u narodnoj nošnji otisnutom na naslovnici. ${ }^{47}$ Koncert s plesom priređen je u velikoj dvorani gradskog kazališta, a u programu su kao izvođači sudjelovali tamburaški zbor sa solistima i mješoviti pjevački zbor. ${ }^{48}$ Ples je nakon koncerta u najboljem raspoloženju potrajao do jutra, a dio ostvarenog prihoda namijenjen je gimnazijskom potpornom društvu. Volja naroda se u svom osvrtu na koncert vrlo povoljno izrazila i o izvođačima i o voditelju. ${ }^{49}$ Budući da se završetak polugodišta 1919./20. iznimno prolongirao na 15. veljače 1920., ranije planirani koncert s plesom Društvo je održalo 6. ožujka. ${ }^{50} \mathrm{Tom}$ prilikom bio je pripremljen birani program koji je obuhvaćao Srpske narodne pesme u obradi Mokranjca, Gerbičeve muške zborove i Devove mješovite zborove te domaće narodne pjesme u obradi F. Dugana. Tamburaški zbor izveo je Blodekovu češku operu $V$ studni. ${ }^{51}$ Ostvareni prihod je, već prema ustaljenom običaju, namijenjen u humanitarne svrhe, a "Slobodni građanin je naglasio kako je u stručnom smislu za uspješnu realizaciju programa odgovoran: njihov zaslužni zborovodja prof. T. Miškulin, koji je kao dobri poznavaoc mješovitih i muških zborova, prožet odličnim razumijevanjem duha naše narodne pjesme, pokazao fino shvaćanje svake pojedine partiture. Pritom je naglasio sljedeće: Svačić je gotovo jedino srednjoškolsko društvo u našoj Jugoslaviji, koje tako marno goji našu narodnu glazbu, te se doista veselimo da naši gimnazijalci pokazuju razumijevanja za umjetnost i za našu narodnu pjesmu." ${ }^{52}$

Povodom 15-godišnjice djelovanja, 21. travnja 1921. Gimnazijsko tamburaško i pjevačko društvo Svačić priredilo je već tradicionalno u kazališnoj dvorani, veliki koncerts plesom. ${ }^{53} \mathrm{Tim}$ povodom tiskana je popratna brošura s rasporedom izvođenja i tekstom izvođenih pjesama..$^{54}$ Velik dio ostvarenog prihoda, kao mnogo puta ranije, namijenjen je ratnoj siročadi. ${ }^{55} \mathrm{U}$ korizmeno vrijeme 1922. s posebnim je

47 Program koncerta Gimnazijskog tamburaškog i pjevačkog društva "Svačić", Varaždin 1919. GMV-72329.

48 "Koncert Svačića", Volja naroda br.12 od 20. ožujka 1919. str. 5.

49 "Koncert Svačića", Volja naroda br.13 od 27. ožujka 1919. str. 2.

50 Slobodni građanin br. 8 od 31. siječnja 1920., str. 4.

51 Slobodni građanin br. 16 od 28. veljače 1920., str. 3.

52 Slobodni građanin br. 27 od 31. ožujka 1920., str. 3.

53 Slobodni građanin br. 13 od 2. travnja 1921., str. 3.

54 Koncert gimnazijskog tamb. i pjevačkog društva Svačić povodom 15-godišnjice u Varaždinu 21. travnja 1921., GMV-72327.

55 Slobodni građanin br. 15 od 16. travnja 1921., str. 4. 


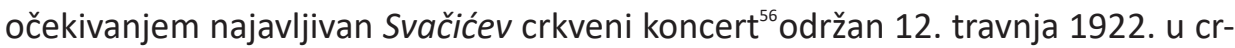
kvi sv. Nikole, a varaždinskom slušateljstvu je omogućio upoznavanje i užitak u slušanju crkvenih pjesama ruskog skladatelja Dimitra Bortnjanskog. ${ }^{57}$ I ovaj koncert je imao humanitarni karakter jer je pola prihoda u iznosu od $1533 \mathrm{Kr}$. darovano podružnici društva Napredak, dok je preostali iznos zadržan za vlastite potrebe. ${ }^{58}$ Jedva mjesec dana nakon crkvenog koncerta Svačić je priredio novi s potpuno drugačijim rasporedom. U subotu 20. svibnja u kazališnoj dvorani uslijedio je koncert s plesom, priređen ponovo u dobrotvorne svrhe.$^{59} \mathrm{U}$ okviru zborskih i tamburaških izvedaba, osobitu pozornost i priznanje su izvanrednom preciznošću izvedbe, zaslužile Bajukove Slovenske pjesme i Slovačke narodne pjesme u izvedbi mješovitog pjevačkog i tamburaškog zbora. Program je obuhvatio i učeničke solističke instrumentalne izvedbe na glasoviru i violini, a suvremeni tisak konstatirao je: "Koncerat uspio je posvema u moralnom, a kako naknadno doznajemo i materijalnom pogledu." ${ }^{60}$

Potkraj sljedeće školske godine, točnije 21. lipnja 1923., Svačić je u kazalištu ponovno priredio koncert s plesom. Ovoga puta na programu su bili hrvatski skladatelji Žganec, Špoljar, Taclik i Mahvić. Tamburaški zbor je nastupio s Farkaševim Hrvatskim prelom, dok je salonski orkestar izveo uvertiru u operu Norma. Umjesto prof. Miškulina, ovoga puta su pjevačkim i tamburaškim zborovima i salonskim orkestrom ravnali učenici, a dio ostvarenog prihoda namijenjen je podupiranju ratne siročadi. ${ }^{61}$ Profesor se s vremenom sve više posvećivao usavršavanju pjevačke vještine kod članova zbora, a vođenje tamburaške aktivnosti prepuštao je starijim učenicima u koje je imao povjerenja. Svačić je svoje javne koncerte, zahvaljujući vrsnom zborovođi, izuzetno dobro pripremao. Barem jednom godišnje, priređivani su koncerti s bogatim sadržajem namijenjeni širem slušateljstvu, koji su bili plakatirani i najavljivani, a nakon izvedbe i često komentirani u tisku. ${ }^{62}$ Posjetitelji su prilikom dolaska na koncert često dobivali program otisnut na više stranica koji je sadržavao raspored izvođenja pojedinih točaka, tekst originalnih skladbi, a ponekad je bio i ilustriran. ${ }^{63}$

\footnotetext{
56 "Crkveni koncert", Narodno jedinstvo br. 12 od 25. ožujka 1022., str. 4.

57 "Crkveni koncert", Narodno jedinstvo br. 15 od 15. travnja 1022., str. 4.

58 "Napredak", Narodno jedinstvo br. 17 od 29. travnja 1022., str. 2.

"Domaće vijesti", Narodno jedinstvo br. 19 od 13. svibnja 1022., str. 5.

"Koncert gimnazijskog tamburaškog i pjevačkog društva Svačić", Narodno jedinstvo br. 22 od 3. lipnja 1922., str. 3.

61 "Koncert. Gimnazijsko tamburaško i pjevačko društvo Svačić", Narodno jedinstvo br. 16 od 21. travnja 1023., str. 4.

62 Gimnazijsko pjevačko društvo „Svačić“ Oratorijska večer crkvenih skladba, Varaždin 2. svibnja 19 25., GMV-KPO 50.

63 Program koncerta Gimnazijskog tamburaškog i pjevačkog društva „Svačić“, Varaždin 1919. GMV72329.
} 


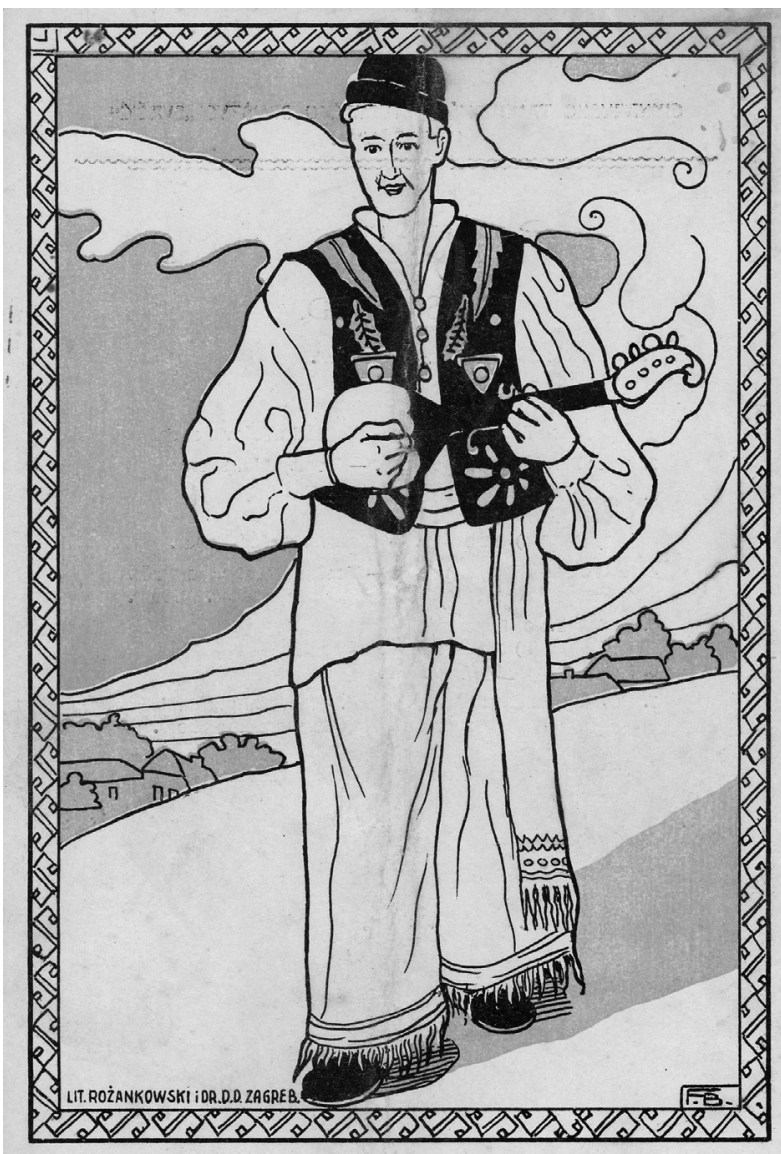

Slika 1. Program koncerta Gimnazijskog tamburaškog i pjevačkog društva „Svačić“, 1919. GMV 72329.

\section{REORGANIZACIJA DRUŠTVA U UVJETIMA MONARHISTIČKE DIKTATURE}

Uvođenjem otvorene kraljeve diktature, totalitarni monarhistički režim je nakon 6. siječnja 1929., pojačao kontrolu nad svim područjima života i rada. To se odnosilo i na prosvjetu gdje se od školskog sustava zahtijevalo da radi na jačanju unitarizma. Prosvjetni kadar je službenim dopisom bio obvezan raditi na njegovom učvršćivanju među učenicima pri čemu se valjalo služiti svim dostupnim 
mehanizmima od izbora nastavnih sadržaja, tema školskih zadaća, referata, propisane lektire, do djelovanja kroz vanškolske aktivnosti. ${ }^{64}$ Zakonom o srednjim školama od 31. kolovoza 1929., pooštren je nadzor nad radom učeničkih udruga. Njime su propisani dozvoljeni oblici udruživanja, sadržaj rada i nadzor nad njihovim djelovanjem. Svrha udruga čiji je rad ipak bio dopušten, mogla je biti samo intelektualno, moralno, estetsko i zdravstveno usavršavanje. Njihov rad mogao se odvijati samo pod stalnim nadzorom uprave škole, a svaka takva udruga morala je imati pravila odobrena od ministra prosvjete..$^{65}$ Umirovljenjem Adolfa Kondrata u ožujku 1929., na dužnost ravnatelja Gimnazije imenovan je prof. Milan Kaman. Osim zalaganja za poboljšavanje metoda nastavnog rada i unapređivanja nastave u cjelini, on se zalagao za rad učeničkih udruga, posebno potičući preoblikovanje i nastavak rada učeničkog društva Svačić i to na znatno široj osnovi nego u ranijem periodu. Sukladno s novim zakonima, rad na osnivanju učeničkog udruženja Svačić započeo je prihvaćanjem prijedloga njegovih pravila na sjednici Nastavničkog savjeta održanoj 14. rujna 1929. godine. ${ }^{66}$ Posredovanjem Banske uprave u Zagrebu prijedlog je upućen Ministarstvu prosvjete u Beograd. Budući da je Banska uprava imala primjedbu na prijedlog da članovi Svačića nose svoje značke te da izdaju svoj list, Ministarstvo je zatražilo ispravak podnesenog prijedloga. Korigirana Pravila udruženja službeno su prihvaćena na sjednici Nastavničkog savjeta škole, održanoj 3. ožujka 1930., a Ministarstvo ih je potvrdilo 8. svibnja pod nazivom Pravila Varaždinskog gimnazijskog udruženja "Svačić“" ${ }^{68}$

Na početku školske godine obično je sazivana godišnja skupština članstva na kojoj se birao odbor i razredni povjerenici, te se utvrđivao program rada novooblikovanog udruženja. Njegova prva glavna skupština održana je 4. lipnja 1930. godine. Na njoj je izabran odbor kojeg su činili predsjednik, potpredsjednik, tajnik, blagajnik i 6 članova koji su birani među učenicima od 3. do 8. razreda. ${ }^{69}$ Broj članova je varirao od minimalno 100-ak, 1934./35 do maksimalno 400 u šk. g. 1938./39. Članovi udruženja mogli su biti učenici svih razreda, a članstvo su potvrđivali članskom iskaznicom. ${ }^{70}$

\footnotetext{
Varaždinska realna gimnazija 1931 - 32, str. 18.

Član 67. Zakonom o srednjim školama od 31. kolovoza 1929. godine.

J. PAVETIĆ, Varaždinska gimnazija između dva rata, Gimnazija - SC „Gabriel Santo“ Varaždin, str. 120-133.

67 Pravila varaždinskog gimnazijskog udruženja „Svačić“, Svačić br. 1-2, rujan-listopad 1930., str. 6.

68 Ministarstvo prosvjete Kraljevine Jugoslavije, Odjeljenje za srednju nastavu S. n. br. 11947.

69 Godišnji izvještaj državne realne gimnazije u Varaždinu, 1930., Đačka udruženja, str. 27.

70 Članska iskaznica Varaždinskog gimnazijskog udruženja "Svačić“, Andrije Hikeca, Varaždin 1937., GMV 88017.
} 


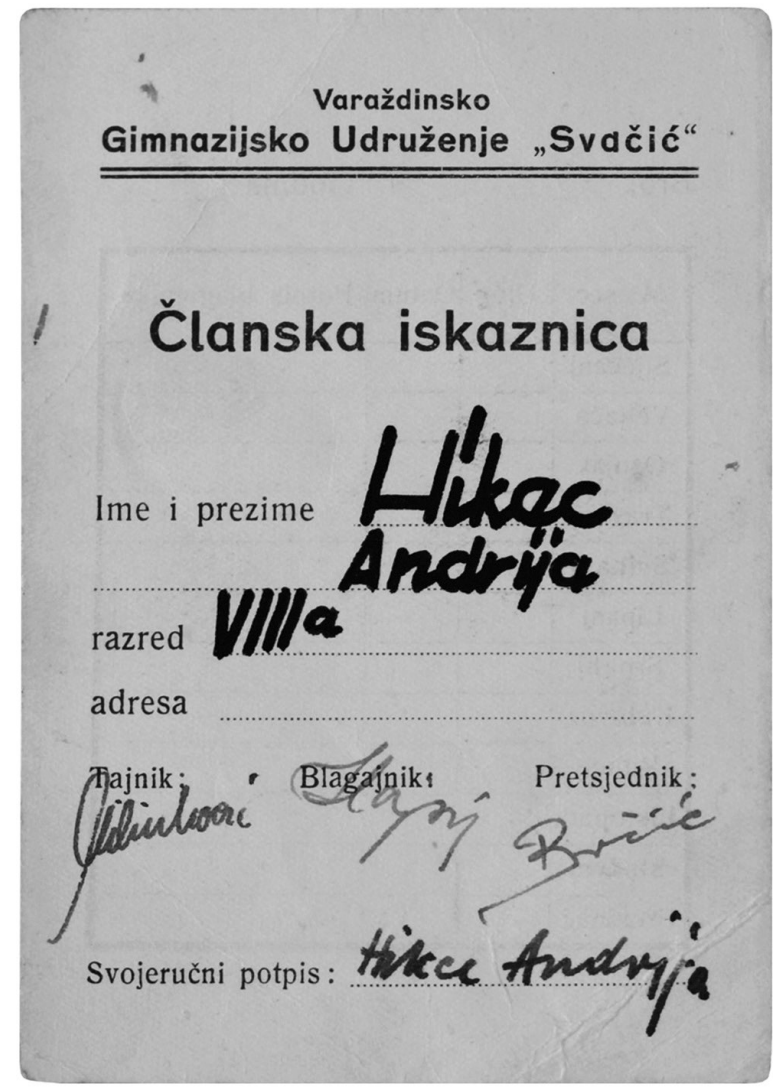

Slika 2. Članska iskaznica Varaždinskog gimnazijskog udruženja Svačić, Andrije Hikeca, 1937., GMV 88017.

Rad udruženja organiziran je kroz sekcije koje su okupljale učenike prema njihovom zanimanju. ${ }^{71} \mathrm{Na}$ čelo sekcija među učenicima su birani pročelnik i dva odbornika Sekcije su predvodili profesori određeni od Nastavničkog savjeta, a nadzor nad radom udruge imao je ravnatelj. ${ }^{72}$ Prema gimnazijskom izvješću za 1929./30. godinu u početku su oformljene: znanstvena sekcija pod vodstvom prof. Franje Koščeca, literarna pod vodstvom prof. Josipa Bognera i glazbena sekcija pod vodstvom prof. Miškulina. ${ }^{73}$ Premda je planirano i osnivanje likovne, turističke i sportske sekcije u navedenom izvješću se ne spominju, već su neke od njih profunkcionirale sljedećih godina.

71 Pravila, članak 2.

72 Pravila, članak 9.

73 Godišnji izvještaj državne realne gimnazije u Varaždinu, 1930., str. 5 - 7. 
Svačićeve sekcije su tijekom školske godine održavale redovite tjedne sastanke, priređujući svoje programe koje su nazivale sijelima. Na taj su način priređivani interni školski programi, ali i priredbe namijenjene široj javnosti kojima se društvo redovito predstavljalo izvan škole, a također su ih nazivali sijelima. Kako je za takve programe u školi bila na raspolaganju samo nekadašnja risaona koju je kao svoju predavaonicu, koristilo Pučko sveučilište, takvi su se programi izvodili u kazalištu, gradskoj sokolani, na sportskom igralištu ili u nekim drugim odgovarajućim prostorima. Već na početku djelovanja u novim uvjetima, udruženje je tijekom 1929./30., priredilo šest javnih priredaba od kojih su čak tri bile zahtjevnije. Ovisno o prirodi i svrsi pripremanih programa, često su ih izvodile dvije ili više sekcija, uglavnom povodom značajnih obljetnica znamenitih osoba iz svjetske i hrvatske prošlosti i kulture. Posebna pozornost posvećivana je obilježavanju rođendana biskupa Strossmayera, povodom čega su priređivani bogati glazbeni, deklamatorni programi i prigodni referati. Smrti narodnih mučenika Petra Zrinskog i Frana Krste Frankopana također su redovno posvećivane priredbe izvođene u prostoru Gimnazije ili čak u Kuršanečkom lugu, pod spomenikom Nikole Zrinskoga. Majčin dan je redovito obilježavan, ponekad unutar škole, a povremeno na višoj razini, dok su se Svačićeve sekcije u program uključivale sa svojim pripremljenim točkama. ${ }^{74}$ Ovakvi programi bili su povodom Božića priređivani redovito svake godine i često su bili otvoreni za javnost pa su se, uz profesorski zbor, učenike i roditelje, na njima okupljali predstavnici vlasti i građani. Premda su najčešće bili dobro posjećeni, povremeno je odaziv bio slabiji. Na Božićnom sijelu održanom 19. prosinca 1931., učenica Milica Kaman, deklamirala je pjesmu Božićne radosti, Novak Valentin iz Vratišinca pripovijedao je o narodnim običajima u međimurskom selu, Mlađan Vera predstavila je Božič u pravoslavnoj kući, a Badanjak Nevenka pripovijedala je vlastita sjećanja na Božić u ranom djetinjstvu i u mladalačkoj dobi. Između pojedinih točaka mješoviti pjevački i tamburaški zbor izvodio je Žgančeve međimurske božićne pjesme, te Macove i Canićeve božićne pjesme. ${ }^{75}$ Kritika je, ne poričući kvalitetu programa, oštro konstatirala: "Veoma se neugodno dojmila velika praznina sokolske dvorane, koju su ispunjavali prazni stolci, bez publike".76

Uvođenjem monarhističke diktature režim je neke datume nametnuo kao državne, posvećujući njihovom obilježavanju posebnu pozornost. Takav su karakter imali: 29. listopada, prekid državno-pravnih veza s Austro-ugarskom, Dan ujedinjenja, Dan sv. Saveili rođendani članova kraljevske obitelji. Povodom toga su, ovisno o

Varaždinska realna gimnazija 1930.- 31., Varaždin. 1931., Ljetopis str. 18-20.

Varaždinska realna gimnazija 1931.- 32., Varaždin. 1932., str. 37.

"Gimnazijsko društvo Svačić", Varaždinske novosti br. 107 od 24. prosinca 1931., str. 5. 
prilikama, priređivane priredbe s programom kojem su svojim nastupima pridonosili članovi pojedinih sekcija, slijedeći pritom zahtjeve režima o izboru prigodnih sadržaja koji veličaju jugoslavenski i unitaristički duh. Na te se manifestacije uz roditelje, obvezno pozivalo predstavnike civilnih i vojnih vlasti. Program pripremljen za obilježavanje 1. prosinca 1930./31., uz tematsko izlaganje o značaju ujedinjenja i popratne glazbene točke, obuhvatio je i polilog Devet banovina $i$ majka Jugoslavija koji su predstavile učenice prvog razreda. ${ }^{77}$ Zakonom o srednjim školama iz 1929. propisano je da se završetak godine obilježava na Vidovdan, uz svečano priopćavanje uspjeha i prigodan program. ${ }^{78}$ Gimnazija je ove svečanosti obogaćivala koncertima. recitalima ili gimnastičkim vježbama pripremanim od Svačićevih sekcija. ${ }^{79}$

$\mathrm{U}$ početku je rad udruge bio znatno otežan jer nije imala prostor u kojem bi se pospremala oprema, rekviziti i instrumenti, a uvježbavanje programa i održavanje redovitih aktivnosti zahtijevali su fleksibilnost i dodatne napore sudionika, no 1931./32. taj problem je riješen. ${ }^{80}$ Zahvaljujući službenom žalovanju zbog atentata na kralja Aleksandra 1934./35. rad društva nije bio obilan kao ranijih godina. ${ }^{81}$ No nakon toga on je ponovno intenziviran, a uz postojeće, osnivane su i nove sekcije. Tijekom 1936./37. godine u okviru društva djelovale su: literarna, znanstvena, glazbena, slikarska, filatelistička, šahovska i sportska sekcija, a osnovana je i čitaonica. ${ }^{82}$

\section{ZNANSTVENA SEKCIJA}

Prema novom ustrojstvu udruženja u njegovu znanstvenu sekciju okupljene su radne jedinice koje su pod vodstvom profesora prirodoslovnih predmeta, dotad uspješno djelovale kao samostalne slobodne aktivnosti. Prema odredbi članka 4 novih Svačićevih Pravila: Zadaća je naučne sekcije pobuđivati interes za prirodne nauke, stvarajući među članovima radne jedinice za razne grane prirodnih nauka.

Premda je Svačićev rad na ostalim područjima bilježio stalni napredak, aktivnost njegove znanstvene sekcije je u ovako izmijenjenim okolnostima počela opadati

\footnotetext{
77 "Godišnji izvještaj državne realne gimnazije u Varaždinu", 1930., Ljetopis zavoda, str. 15.

78 "Zaključak školske godine na realnoj gimnaziji", Varaždinske novosti br. 82 od 2. srpnja 1931., str. 1.

79 Gimnazijska izvješća od 1930. do 1939. godine.

80 "Godišnji izvještaj državne realne gimnazije u Varaždinu", 1931.- 32., Đačka udruženja, str. 37.

81 "Drž. realna gimnazija u Varaždinu", Godišnji izvještaj za školsku godinu 1934.- 35., str. 45.

82 "Drž. realna gimnazija u Varaždinu", Godišnji izvještaj za školsku godinu 1936.- 37., str. 61.
} 
s obzirom na raniji rad spomenutih radnih jedinica. Niti u Pravilima, ni u praksi, one više nisu funkcionirale kao posebne istraživačke skupine koje njeguju dodatni rad s nadarenim učenicima. Taj se rad dotad organizirao izvan procesa redovite nastave i temeljen je na izradi pribora, prikupljanju uzoraka te samostalnom učeničkom istraživanju, izvođenju pokusa, promatranju i mjerenju.

Za voditelje sekcije povremeno su bili imenovani profesori prirodoslovnih, ali i humanističkih predmeta. Pod vodstvom čuvenog varaždinskog prirodoslovca Franje Košćeca sekcija je 1929./30. u vlastitoj nakladi izdala Tabele za fenološka opažanja. Uz redovito sudjelovanje učenika koji bi ih sustavno i savjesno ispunjavali prikupljenim podatcima, na Gimnaziji se pokušavalo osnovati stalnu fenološku postaju. ${ }^{83}$ No $1930 . / 31$. na dužnost voditelja imenovan je povijesničar Zvonimir Čeliković, pa je aktivnost svedena na obrađivanje povijesnih sadržaja. U skladu s novim trendom, sekcija je svojim sijelom 23. studenoga 1930. obilježila 300-godišnjicu smrti astronoma Johana Keplera u okviru kojeg je prof. Vladimir Deduš predstavio temu Zašto slavimo spomendane velikih umova?, a kroz učeničke referate predstavljen je povijesni razvoj astronomije i rad spomenutog astronoma ${ }^{84}$ Tijekom 1932/33., zbog nedovoljnog broja prijavljenih učenika, sekcija uopće nije funkcionirala. ${ }^{85} \mathrm{Njezin} \mathrm{rad} \mathrm{u} \mathrm{novim} \mathrm{se} \mathrm{okolnostima} \mathrm{odvijao} \mathrm{kroz} \mathrm{tzv.} \mathrm{si-}$ jela, sastanke u okviru kojih su svi zainteresirani sudjelovali u diskusiji na zadanu temu. Kao podloga za raspravu obično su poslužili referati koje su na unaprijed dogovorenu temu, izložili najaktivniji članovi. U godini 1936./37. održano je 5 sastanaka na kojima se raspravljalo o: postanku života, razvoju sunčanog sistema, sastavu atmosfere i geološkim pitanjima. Održana su i tri učenička predavanja: Sunčeva obitelj, Stanica i Sredstva praktične astronomije. ${ }^{86}$ Godine 1937./38. sekcija je održala tri sijela od kojih je posebnu pozornost privukla tema Morska svietlila. ${ }^{87}$ Predavanje je održao učenik 7. razreda Ivan Petanjek, a uz brojne učenike, pratili su ga i neki profesori. ${ }^{88}$ Sljedeće godine priređena su svega dva učenička predavanja: Mesojedne biljke i $O$ stanici, popraćena projekcijama i modelima, što im je znatno povećalo atraktivnost. ${ }^{89}$ Do kraja međuratnog razdoblja sekcija je ipak i dalje funkcionirala, no njezin rad nažalost je sveden na nekoliko sastanaka godišnje, a sadržaj rada na par predavanja. Sustavni samostalni praktični rad učenika polako je zamirao. Prerastao je u teorijsko izučavanje određenih tema u okviru kojih se aktivnost polaznika uglavnom svodila na prezentaciju proučenog i diskusiju.

83 Godišnji izvještaj državne realne gimnazije u Varaždinu, 1930., Đačka udruženja, str. 26-27.

84 Godišnji izvještaj državne realne gimnazije u Varaždinu, 1931., Đačka udruženja, str. 42-43.

85 Godišnji izvještaj državne realne gimnazije u Varaždinu, 1933., str. 45.

86 "Drž. realna gimnazija u Varaždinu", Godišnji izvještaj za školsku godinu 1936-37, str. 61.

87 "Drž. realna gimnazija u Varaždinu", Godišnji izvještaj za školsku godinu 1937-38, str. 32.

88 "Predavanje u Svačiću", Varaždinske novosti br. 420 od 16. prosinca 1937., str. 5.

89 "Drž. realna gimnazija u Varaždinu", Godišnji izvještaj za školsku godinu 1938-39, str. 29. 


\section{GLAZBENA SEKCIJA}

Glazbena djelatnost bila je najstarija aktivnost u udruzi. Pod vodstvom prof. Miškulina ona je i nadalje nosila gotovo sve kulturno-umjetničke programe u Gimnaziji, a često i izvan nje, pridružujući se nizu dobrotvornih koncerata i raznorodnih programa. Pod njenim se okriljem i u reorganiziranom udruženju nastojalo razvijati pjevanje i tamburaštvo, a njegovalo se i individualno sviranje pojedinih instrumenata, posebno glasovira i violine. Osim uvježbavanja programa za brojne nastupe, sekcija je organizirala tečajeve sviranja na tamburama, koje su obično vodili stariji učenici.

Samostalno ili surađujući s drugim sekcijama, glazbena sekcija je priređivala više većih nastupa godišnje, sudjelujući na svečanim akademijama povodom obilježavanja važnih datuma, službenih praznika ili na dobrotvornim priredbama izvan Gimnazije. Dana 23. studenoga 1929. u dvorani gradskog kazališta održan je koncert u okviru kojeg su nastupili pjevački i tamburaški zbor, zatim je izvedena točka za klavir i violinu i jedna ritmička vježba. ${ }^{90} \mathrm{Uz}$ šaljive uvodne deklamacije i tri pjesme u izvedbi glazbene sekcije, 22. veljače 1930., priređena je kazališna predstava Stričeva oporuka, dok je 10. svibnja iste godine Svačić sa svojim tamburaškim i pjevačkim točkama sudjelovao u koncertnom dijelu maturalne zabave.

U subotu, 23. prosinca 1929. priređen je prvi koncert za javnost, organiziran u novim okolnostima. ${ }^{91}$ Kritika je nastup ocijenila kao vrlo uspjeli, odajući priznanje tamburaškom zboru i sugerirajući veći naglasak na nacionalnom repertoaru. Pohvaljen je i nastup pjevačkog zbora, uz konstataciju da je koncert uspio u moralnom i u materijalnom pogledu jer je dvorana bila puna gostiju među kojima i mnogih odličnika. Od ostvarenog prihoda, već u 1929./30. godini nabavljene su nove tamburice, stalci za note i veći broj novih skladbi. Godine 1930. Svačićev pjevački i tamburaški zbor nastupili su na koncertnom dijelu maturalne zabave. ${ }^{92}$ Obilježavanje Majčinog dana 18. svibnja 1930. organizirao je savez varaždinskih ženskih društava, a u programu svečane matineje sudjelovali su i Svačićev tamburaški i pjevački zbor. ${ }^{93}$

Budući da joj je zbog porasta broja razrednih odjela, morala biti oduzeta soba za vježbanje, glazbena sekcija bila je tijekom sljedeće godine ograničena u djelovanju. To je ujedno bio razlog zašto nije bilo stalnih tamburaških proba. ${ }^{94}$ Usprkos tome mješoviti zbor sudjelovao je u redovitom obilježavanju zna-

\footnotetext{
"Godišnji izvještaj državne realne gimnazije u Varaždinu", 1930., Đačka udruženja, str. 26. Koncert gimnazijskog udruženja Svačić, Varaždinske novosti, br. 1 od 12. prosinca 1929., str. 4. Godišnji izvještaj državne realne gimnazije u Varaždinu, 1930., Đačka udruženja, str. 26-26. Isto, Ljetopis, str. 10.

94 Varaždinska realna gimnazija 1930-31, Varaždin. 1931., str. 43.
} 
čajnih datuma pa su na dan raskida državnopravnih odnosa s Monarhijom 1930., uz prigodno predavanje u program uvrštene točke Svačićevog pjevačkog i tamburaškog zbora.

Na dan sv. Save, izveli su, kao i uvijek, svetosavsku himnu, dok je ovoga puta bila izvedena i 8. rukovet Mokranjčevih Srpskih narodnih pesama i Gostinčareva Neka nam živi Jugoslavija. Dana 3. veljače 1931. glazbena i literarna sekcija priredile su u gradskoj gombaoni zajedničko sijelo, kao školsku proslavu Strossmayerovog dana. ${ }^{95} \mathrm{Na}$ programu su bile deklamacije, kratko predavanje, pjevačke i tamburaške točke, a nakon koncertnog dijela, zabava s plesom, uz pratnju Svačićevog jazz-orkestra. ${ }^{96} \mathrm{Na}$ dan narodnih mučenika Zrinskog i Frankopana 30. travnja 1931. Svačićev mješoviti zbor sudjelovao je u programu kod spomenika Nikoli Zrinskom u Kuršanečkom lugu, izvođenjem državne himne i Gostinčareve pjesme Neka nam živi Jugoslavija. ${ }^{97}$ Osim u gimnazijskim programima, svojim pjevačkim i tamburaškim točkama, glazbena sekcija sudjelovala je i u programima izvan Gimnazije. Između ostalog, pjevački i tamburaški zbor nastupili su na sijelu Sokolskog društva Varaždin održanom 16. svibnja 1931. godine. ${ }^{98}$ Kako je 1931./32. udruzi bila osigurana soba, redovite tamburaške probe su se nastavile pod vodstvom prof. Zgorelca i Šprema te učenika Šrenka, a pjevačke probe bile su redovite. Pjevački zbor je na proslavi sv. Save, uz redovitu svetosavsku himnu,

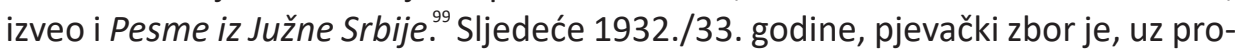
slavu sv. Save, nastupio na proslavi rođendana biskupa Strossmayera te na bogatoj glazbenoj produkciji priređenoj 14. svibnja 1933. godine. Na maturantskom dobrotvornom koncertu 1. veljače 1933., svojim nastupom zboru je podršku pružila Gabrijela Horvat, bivša primadona praške opere. Na toj priredbi nastupio je i tamburaški zbor pod ravnanjem Mor Darka učenika 6. razreda.$^{100} \mathrm{Uz}$ već spominjane manifestacije, 1933./34. godine pjevački zbor pridonio je obilježavanju Majčinog dana koje je 13. svibnja 1934, priredio Podmladak Crvenog Križa te na glazbenoj produkciji 31. svibnja, održanoj u gradskoj gombaoni. Redovite probe tamburaškog zbora vodili su učenici. ${ }^{101}$

Zbog žalovanja povodom atentata na kralja Aleksandra, rad društva u šk. g. 1934./35. nije bio tako obilan kao ranije. Ipak, najaktivnija od svih sekcija bila je glazbena sekcija, koja je imala stalne probe pod vodstvom prof. Miškulina, a tam-

Isto, str. 14-17.

96 Varaždinsko gimnazijsko udruženje Svačić, Varaždinske novosti br. 60 od 29. I. 1931., str. 4.

97 Varaždinska realna gimnazija 1930-31, Varaždin. 1931., str. 18-19.

98 Sokol Kraljevine Jugoslavije, Varaždinske novosti, br. 76 od 21. V. 1931., str. 2.

99 Godišnji izvještaj državne realne gimnazije u Varaždinu 1931- 32., str. 27-37.

100 Godišnji izvještaj državne realne gimnazije u Varaždinu 1932- 33., str. $45 .$.

101 Drž. realna gimnazija u Varaždinu, Godišnji izvještaj za školsku godinu 1933-34, str. 22. 
buraški zbor imao je tri tečaja pod vodstvom sedmoškolca Božidara Ostojića. Samostalnih javnih nastupa izvan škole nije bilo, već je pjevački zbor sudjelovao u programima svih važnijih priredaba u školi. Među njima valja izdvojiti kvalitetancrkveni koncert održan 7. travnja 1935. kad je gimnazijski pjevački zbor nastupio uz soliste barunicu Hedu Jordis na violini i orguljaša Franju Dugana, profesora zagrebačke glazbene akademije koji ga je posebno pohvalio kao jedan od najboljih školskih zborova u zemlji. ${ }^{102}$ Tijekom sljedeće godine rad sekcije bio je obilat. Tamburaški zbor pokazao je svoju vještinu na sijelima, a naročita briga bila je posvećena stvaranju tamburaškog podmladka ${ }^{103}$ Dana 5 . ožujka 1936. priređena je dobro posjećena glazbena produkcija na kojoj su izvođene skladbe slavenskih skladatelja. Pjevački zbor nastupao je na svim školskim priredbama i vježbao se za nastup u proslavi nadolazeće 300-godišnjice Gimnazije.

U okviru dvodnevnog programa obilježavanja 300 -godišnjice varaždinske Gimnazije, glazbena sekcija je dala doprinos svojim koncertom i nastupom na svečanoj akademiji. Pripremu glazbenog dijela programa proslave prof. Miškulin započeo je već 1934. godine. Kako je u programu proslave primarno nastojao predstaviti skladbe domaćih skladatelja i izvorne skladbe ovih krajeva, osobno se obratio uglednim glazbenicima, nekadašnjim varaždinskim gimnazijalcima: Josipu Vrhovskom, Josipu Štolceru Slavenskom, Vjekoslavu Ružiću-Rosenbergu, Nikoli Falleru, Franji Duganu i Vinku Žgancu, koji su se rado odazvali, šaljući mu skladbe od kojih su neke bile skladane isključivo za ovu priliku. Koncert je održan u koncertnoj dvorani gradskog kazališta u subotu 3. listopada 1936., navečer. Mješoviti zbor gimnazijske mladeži od 150 članova, pojačan sa svega 20 posto bivših učenika, pratio je orkestar vojne glazbe sastavljen uglavnom od bivših učenika varaždinske Gimnazije. Kao solisti su nastupili također bivši učenici i učenice: Irma Šprem, slušač Glazbene akademije u Zagrebu, učiteljica glasovira, Štefica Pokaz, župnik Ignacije Keretić i dr. Marijan Grims. ${ }^{104}$ Nakon izvođenja državne himne uslijedio je program koncerta sastavljen uglavnom od skladbi bivših učenika ove škole skladanih za ovu priliku. Izvedbom je ravnao osobno prof. Miškulin, a koncert su prenosile sve radio-postaje, uz komentar prof. Krešimira Filića. U publici su, uz dužnosnike i predstavnike srednjih škola i kulturnih ustanova, sjedili i skladatelji.

Unedjelju4. listopadasudionici proslave prisustvovalisu svečanojmisiugimnazijskoj crkvi tijekom koje je gimnazijski mješoviti zbor, uz pratnju orkestra i osobnu

102

103

104

Drž. realna gimnazija u Varaždinu, Godišnji izvještaj za školsku godinu 1934-35, str. 26-45.

Drž. realna gimnazija u Varaždinu, Godišnji izvještaj za školsku godinu 1935-36., str. 32.

Drž. realna gimnazija u Varaždinu, Godišnji izvještaj za školsku godinu 1936.- 37., Tečaj proslave, str. $15-25$.

Isto, Ljetopis, str. 38. 
pratnju prof. Dugana na orguljama, izveo Hrvatsku misu Josipa Vrhovskoga, skladanu upravo za ovu priliku. Nakon mise uslijedio je Duganov Tebe Boga hvalimo na riječi Marka Marulića, uz ravnanje prof. Miškulina. U okviru svečane akademije priređene u koncertnoj dvorani gradskog kazališta, prenošene putem radija, gimnazijski mješoviti zbor izveo je Zagorsku rapsodiju Vinka Žganca ${ }^{105}$ Prema zapisu prof. Miškulina, neposredno nakon izvedbe, neki bivši članovi zbora zapjevali su Lijepu našu, što je prihvatio cijeli zbor i dobar dio slušateljstva. Zbog toga je prof. Miškulin prilikom dodjele odlikovanja, ostao bez ordena. Čitav ovaj glazbeni program oblikovan je, pripremljen i briljantno izveden, zahvaljujući neumornom i samoprijegornom radu članova glazbene sekcije koji su predvođeni svojim zborovođom, zadržali entuzijazam i upornost da se tijekom nekoliko mjeseci pripremaju i vježbaju uz suradnju nekadašnjih učenika i ranijih članova zbora. Za sav trud i izniman uspjeh ovog programa bili su nagrađeni oduševljenim reakcijama slušateljstva, a Varaždinske novosti su im posebnim člankom javno izrazile zahvalnost i priznanje..$^{106}$

Pjevački zbor tada je okupljao velik broj učenika svih razreda i funkcionirao je kao mješoviti pjevački zbor sa sva četiri glasa. Zbog brojnog članstva vježbanje se odvijalo razdvojeno po glasovima i po spolu, sa svakom grupom dva puta tjedno po jedan sat. Nakon toga posebno su održavane zajedničke probe cijelog zbora. ${ }^{107}$ Dva i pol mjeseca nakon proslave, točnije 19. prosinca 1936. maturanti su u gradskoj gombaoni priredili Božićno sijelo. U okviru programa sudjelovali su barunica Heda Jordis, Svaćićev mješoviti zbor i tamburaški zbor, a nakon službenog dijela programa priređena je čajanka s plesom. ${ }^{108}$ Od godine 1937 . kao solisti su u okviru koncerata Svačićeve glazbene sekcije nastupali tadašnji učenici ove gimnazije Josip Klima i Jurica Muraj. ${ }^{109}$

Uz sudjelovanje u ostalim programima, 1937./38., pjevački zbor je 14. svibnja 1938. održao i javni koncert u Čakovcu. Članovi su u početku za tamburašku aktivnost pokazivali vrlo veliko zanimanje, ali tijekom godine ono je znatno opalo. ${ }^{110}$ Godine 1938./39. Svačićev orkestar nastupao je na svim gimnazijskim

\footnotetext{
106 "Jedna posebna pohvala našem profesoru Miškulinu", Varaždinske novosti br. 358, 8.X. 1936., str. 4.

107 HISTORIJSKI ARHIV VARAŽDIN, fond: Gimnazija Varaždin Dnevnik rada za zborno pjevanje 1936/37 - 1940/41.

108 Božićno sijelo sa čajankom 19. XI. 11936., GMV-KPO 8671.

109 Krešimir FILIĆ: Glazbeni život Varaždina, Varaždin, 1972, str. 99-101.

110 Drž. realna gimnazija u Varaždinu, Godišnji izvještaj za školsku godinu 1937.- 38., str. 16-32.
} 


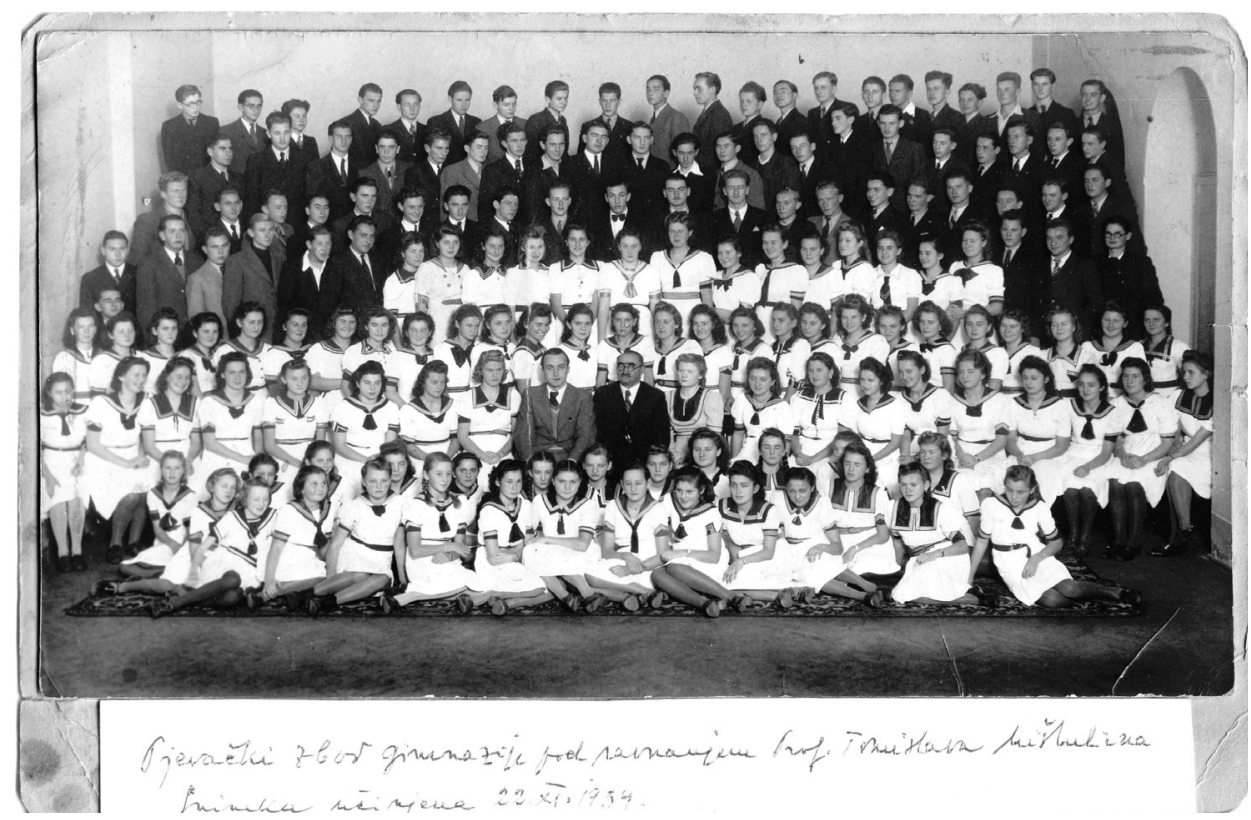

Slika 3. Pjevački zbor Gimnazije pod ravnanjem T. Miškulina 22. studenoga 1939. godine

Tom prilikom su, uz pratnju profesora glazbene akademije Franje Dugana na orguljama i podršku bivših učenika Gimnazije kao solista, izvođena uglavnom Duganova djela i obrade priređene za zbor, solo i orgulje, ${ }^{113}$ među kojima i misa iz rukopisa varaždinskog franjevačkog samostana koju je obradio prof. Dugan. Koncert je u popodnevnim satima, održan za srednjoškolsku mladež, a navečer je ponovljen za građanstvo. Kako su kritika i tisak koncert okarakterizirali kao izuzetno uspješan i kvalitetan, zboru su bila otvorena vrata Hrvatskog Glazbenog zavoda. No prije toga, 29. travnja 1940., povodom pogibije Zrinskog i Frankopana bila je priređena raskošna akademija s bogatim glazbenim programom i predavanjem prof. Filića. ${ }^{114}$

Nastup u Hrvatskom Glazbenom Zavodu uslijedio je 29. svibnja 1940. godine. Za tu priliku je gimnazijski pjevački zbor priredio koncert vokalnih zborskih skladbi hrvatskih skladatelja. I ovaj su nastup kritika i tisak ocijenili kao vrlo uspješan, hvaleći pritom i zbor i zborovođu. Jutarnji list od 30. svibnja 1940. navodi kako je Miškulin potvrdio: "svoju energiju,... sposobnost da sa svojim mladim pjevačima

113 Drž. realna gimnazija u Varaždinu, Godišnji izvještaj za školsku godinu 1939.- 40., Koncerti pjevačkog mješovitog zbora gimnazijske mladeži, str. 34-38.

114 Isto, Ljetopis, str. 15. 
radi sustavno, da ih uputi u skladno pjevanje, da u njima probudi ljubav za glazbom".

Hrvatski Dnevnik od 31. svibnja 1940. konstatirao je kako je zborovođa morao uložiti silan napor, izdržljivost, glazbeno znanje i edukativnu sposobnost dok je taj zbor tako dotjerao i izvođene skladbe tako pomno uvježbao. O nastupu su izvještavali i drugi listovi, ${ }^{115}$ a brojne pohvale upućene su i novootkrivenom glazbenom talentu, Jurici Muraju koji je nastupio kao solist na glasoviru. Ovaj je nastup bio svojevrsna kruna glazbenog djelovanja gimnazijskog zbora i njegovog voditelja u međuratnom razdoblju. Rezultat tog neumornog rada bio je kvalitetan mješoviti pjevački zbor, sposoban za izvođenje složenih zborskih skladbi. Valja naglasiti da su brojni varaždinski gimnazijalci radom u glazbenoj sekciji i angažmanom prof. Miškulina, stekli temeljna glazbena znanja, a neki od njih su se razvili u kvalitetne glazbenike.

\section{LITERARNA SEKCIJA}

Do uklapanja u novooblikovano učeničko društvo, literarna sekcija je uspješno djelovala kao samostalna, slobodna učenička aktivnost koja je svojim prilozima pridonosila manifestacijama priređivanim povodom pojedinih važnih događanja. U suradnji s Glazbenom sekcijom ona je i u novim okolnostima bila nositelj takvih programa priređivanih u školi i izvan nje. U takvim prilikama njeni su članovi iznosili referate na zadanu temu, čitali vlastite sastavke, deklamirali, interpretirali i izvodili predstave, pridružujući se često dobrotvornim programima i akcijama. Prema novim Svačićevim Pravilima, glavni zadatak sekcije bio je: upoznavanje lijepe književnosti slavenskih i ostalih evropskih naroda, a sredstva za to biće sijela i pozorišne predstave pod rukovođenjem školske vlasti. ${ }^{116} \mathrm{Kao}$ područje djelovanja sekcija je odredila njegovanje samostalnog književnog izražavanja učenika, sudjelovanje u brojnim priredbama u školi i izvan nje te rad na izdavanju učeničkog lista. Djelovala je putem sijela, održavajući redovite tjedne sastanke na kojima su sudjelovali članovi svih razreda. Kako je cilj bio vježbanje u pravilnom glatkom čitanju, živom pripovijedanju i deklamiranju, članovi su na sijelima čitali vlastite pjesmice i referate i uvježbavali spomenute vještine. ${ }^{117}$ Ove vježbe odvijale su se

\footnotetext{
115 O nastupu su izvještavali još: Novosti 31. V., Zagrebački List 31. V. i Hrvatski list u Osjeku 1. lipnja 1940.

116 Pravila, čl. 3.

117 Varaždinska realna gimnazija 1930.- 31., Varaždin. 1931., str. 43.
} 
pod vodstvom za to zaduženih profesora pa je u početku taj rad nadzirao prof. Stjepan Šprem, postižući pritom značajan uspjeh. Sljedećih godina u vođenje sekcije uključili su se prof. Martin Balić, Petronila Ferkovič ${ }^{118}$ i Franjo Galinec. Dotadašnjem radu pridodano je i vježbanje u govorničkoj vještini. Premda je u početku rad bio otežan zbog problema s prostorom, sekcija je pretplaćena na neke važnije literarne revije te su tako stvarani temelji buduće učeničke čitaonice. ${ }^{119}$ No kad je 1931./32. godine za Svačićev rad osigurana posebna soba ${ }^{120}$ u njoj su smješteni ormari s knjigama i glazbenim instrumentima, a literarna sekcija mogla je za potrebe članstva, raditi na osnivanju svoje čitaonice.

Sekcija je povremeno priređivala posebna sijela posvećena radu pojedinih književnika pa su na svojem prvom sijelu 1930./31., priređenom 9. studenoga, njeni članovi obilježili 2000-godišnjicu rođenja čuvenog rimskog pjesnika Publija Vergilija Marona, poprativši iznesene referate recitalima i čitanjem odgovarajućih tekstova. ${ }^{121}$ Dana 8. prosinca 1931. u dvorani Pučkog sveučilišta obilježena je 50-godišnjica smrti Augusta Šenoe, a godine 1933. priređena su sijela povodom 100-godišnjice rođenja srpskog pjesnika Zmaja Jove Jovanovića i 25-godišnjice smrti Silvija Strahimira Kranjčevića. ${ }^{122}$ Njihov program sastojao se iz deklamacija i prigodnih referata. ${ }^{123}$ Godine 1935./36. održano je sijelo posvećeno francuskom književnik u Paulu Bourgetu o kojem je iscrpan referat iznio pročelnik sekcije, a čitani su i karakteristični odlomci njegovih tekstova. ${ }^{124}$

Na učeničkom sijelu 3. veljače 1931., priređenom povodom Strossmayerova dana, uz glazbene točke u program su bili uvršteni učenički referati na zadanu temu i prigodni recitali. ${ }^{125}$ Strossmayerov dan 1933., obilježen je svečanom matinejom svih državnih škola u varaždinskom kazalištu u čijem programu je Gimnazija, uz nastup pjevačkog zbora, sudjelovala s odgovarajućim recitalom. Tijekom 1932./33. godine održano je čak 14 literarnih sijela, a sljedeće godine priređeno je 7 internih uz 2 javna literarna sijela. ${ }^{126}$ lako, zbog atentata na kralja Aleksandra, rad društva tijekom 1934./35. nije bio obilan kao prošlih godina, sekcija je odr-

\footnotetext{
118 Godišnji izvještaj državne realne gimnazije u Varaždinu 1932.- 33., str. 45. 
žala pet sijela na kojima su uglavnom čitani vlastiti sastavci. No redovito su obilježavane značajnije obljetnice poput 100-godišnjice llirskog pokreta, 19. svibnja 1935. u suradnji s gimnazijskom Zajednicom doma i škole. Uz brojne glazbene točke i izlaganje prof. Balića na temu Veličina i snaga ilirske ideje i niz prigodnih deklamacija, tu su kroz učeničke referate bili predstavljeni portreti poznatih Iliraca. ${ }^{127}$ Sljedeće godine priređeno je 10 sijela od kojih su zapaženija bila Božićno sijelo i sijelo u spomen na Faula Bourgeta. Na programu božićnog sijela 22. prosinca 1935., uz pripovijedanje božićnih običaja te izvođenje tamburaških, glasovirskih i violinskih točaka, bile su uvrštene i literarne točke, a nakon izvedenog programa održana je zabava s plesom. Prigodni kulturno-umjetnički programi priređivani su redovito, povodom pogibije Zrinskog i Frankopana. Na akademiji organiziranoj tim povodom 1936. godine, zbor učenika 6. razreda priredio je program tijekom kojeg su se Zajčeve arije izmjenjivale $s$ prigodnim referatima, recitalima i glazbenim točkama, a sličan program priređivan je i ubuduće. Program ostalih sijela bio je ispunjen originalnim pokušajima na polju lirike i novele. Stihovi članova bili su s uspjehom recitirani na maturalnoj zabavi i učeničkoj glazbenoj priredbi. Radovi čitani na sijelima tiskani su u učeničkom literarnom listu, a neki i u zagrebačkim književnim revijama. ${ }^{128}$ Tijekom 1936./37. osnovana je čitaonica koja je primala brojne časopise i posjedovala 130 knjiga. ${ }^{129}$ Godine 1937./38. sekcija je održala 6 sijela, a na njihov rad se povremeno osvrtao i domaći tisak. Varaždinske novosti izvijestile su kako je 19. studenoga 1937. održano sijelo literarne sekcije Svačića, na kojem su se čitali originalni radovi na polju lirike, pripovijetke i folklore, te je konstatirano da je sijelo bilo vrlo dobro posjećeno. ${ }^{130}$ Iste godine priređeno je i jedno glazbeno-literarno sijelo, a na zabavi priređenoj nakon njega, svirao je društveni orkestar. ${ }^{131}$

Jedan od glavnih planiranih zadataka literarne sekcije bio je uređivanje i izdavanje učeničkog lista Svačić čije izlaženje monarhistički režim u početku nije dozvoljavao. Zalaganjem tadašnjeg ravnatelja Milana Kamana, početak njegovog izlaženja dozvoljen je tek nakon nekoliko ponovljenih molbi Ministarstvu prosvjete tijekom $1930{ }^{132}$ godine. Tek kad je zajamčeno da će se u listu objavljivati

127 Drž. realna gimnazija u Varaždinu, Godišnji izvještaj za školsku godinu 1934.- 35., Ljetopis, str. 2829.

128 Drž. realna gimnazija u Varaždinu, Godišnji izvještaj za školsku godinu 1935.- 36., str. 20-32.

129 Drž. realna gimnazija u Varaždinu, Godišnji izvještaj za školsku godinu 1936. -37., str. 61.

130 "Život na gimnaziji", Varaždinske novosti br. 417 od 25. XI. 1937., str. 4.

131 Drž. realna gimnazija u Varaždinu, Godišnji izvještaj za školsku godinu 1937.- 38., str. 32.

132 Historijski arhiv Varaždin, fond: Gimnazija Varaždin - spisi 86/1930. 97 1930. i 220/1930. 
isključivo učenički literarni radovi, a da list neće biti prodavan, već besplatno dijeljen članstvu, njegovo izlaženje ipak je dopušteno. Varaždinski tisak pozdravio je njegovo izdavanje, hvaleći napore profesora i ravnatelja u nastojanju da ga se pokrene. ${ }^{133}$ Zamišljen je kao mjesečnik s četiri do šest stranica te je tijekom 1929./30. godine, izdano sedam brojeva. Varaždinske novosti su analizirale njegov sadržaj, konstatirajući kako uvodnik pokazuje lijepu suradnju nastavnika i učenika te kako tu ima: pjesmica, lijepih opisa izleta, geografskih crtica i raznih drugih referata. Naglašeno je da ni Svačić ne može biti: bez križaljki, zagonetki $i$ sličnih zabavnih atrakcija koje imaju i tu dobru osobinu da obrađuju djački život. Posebno je zanimljiv poziv: Roditelji, čitajte „Svačić!" kojim je zaključen spomenuti članak. ${ }^{134}$

U drugoj godini izlaženja 1930/31. objavljeno je 10 brojeva s raznolikim sadržajem, a u listu su surađivala 53 suradnika iz svih razreda $\cdot{ }^{135}$ No sljedeće godine bila su objavljena samo četiri broja, a 1933./34. nije izašao nijedan broj, kako je navedeno radi materijalnih teškoća, premda je postojala dobra suradnička mreža. Tek 1936./37. godine izdan je još samo jedan broj, a zatim više list nije izdavan, jer nije bilo sredstava. ${ }^{136}$ Društvo je na početku 1938./39. godine ponovno planiralo objavljivati učenički list u kojemu bi surađivali svi članovi i zamišljen je kao ogledalo učeničkog rada u školi. No nažalost u nedostatku potrebnih sredstava, nije bio objavljen niti jedan njegov broj.

\section{SPORTSKA SEKCIJA}

Premda nakon Prvog svjetskog rata nije bio obnovljen Varaždinski gimnazijski športski klub, zahvaljujući radu učitelja vještina, Zvonimira Suligoja, sportska aktivnost u gimnaziji dosegla je visoku razinu, utičući i na razvoj sporta u gradu. Upravo gimnazijalci su 1930. godine, odigrali prvu službenu rukometnu utakmicu u Hrvatskoj i tadašnjoj Jugoslaviji, a gimnastičari iz varaždinske Gimnazije sudjelovali su na brojnim sokolskim sletovima premda za pripreme nisu imali vlasportsku dvoranu, a za svoj rad i redovnu nastavu koristili su igralište Sportskog kluba Slavija. ${ }^{137}$

\footnotetext{
133 "Svačić" glasilo varaždinske gimnazijske omladine, Varaždinske novosti br. 7 od 23. I. 1930., str. 2.

134 "Svačić" glasilo varaždinske gimnazijske omladine, Varaždinske novosti br. 69 od 4. IV. 1931. str. 4

135 Varaždinska realna gimnazija 1930. -31,. Varaždin. 1931., str. 43.

136 Drž. realna gimnazija u Varaždinu, Godišnji izvještaj za školsku godinu 1938.- 39., Đačke udruge, str. 30

137 J. Pavetić: Isto, str. 133.
} 
Sekcija je okupljala gimnazijalce koji su se bavili atletikom, tenisom, skijanjem, klizanjem i rukometom. Potkraj svake školske godine, najčešće u svibnju, gimnazijski sportaši su obično priređivali gimnastičku produkciju u okviru koje bi se javnosti predstavile gimnastičke i atletske vježbe i sportske igre. Obično su je održali u prostoru gradske gombaone ili na sportskom igralištu pred okupljenim gimnazijalcima, roditeljima, građanstvom i pozvanim predstavnicima vlasti. Dana 29. svibnja 1930., na sportskom igralištu je održana gimnastička produkcija s jednostavnim atletskim vježbama na spravama i igrama. Svrha je bila propagirati sokolski slet u Beogradu i prikupljanje novca za pomoć učenicima koji će putovati na slet. Odaziv građanstva bio je velik. ${ }^{138}$ Dana 5 . lipnja 1932., već pripremljena gimnastička smotra, zbog lošeg vremena, umjesto na igralištu, održana je u kazalištu. Tom prilikom izvođene su proste vježbe, a prisustvovali su im ministrov izaslanik, predstavnici civilnih i vojnih vlasti i roditelji. ${ }^{139}$ Takve smotre povremeno su pripremane s učenicima ostalih varaždinskih škola, pa je 25. svibnja 1933., na vježbalištu sokolane priređena zajednička javna gimnastička priredba s učenicima Građanske škole i obiju osnovnih škola. Uz proste vježbe svih kategorija ovoga puta predstavljene su vježbe na spravama, bacanje kugle, igre i potezanje užeta.$^{140}$ Gimnastička produkcija u zajedničkoj izvedbi s učenicima Građanske škole održana je 27. svibnja 1937. godine. Izvedene su: proste vježbe, proste slikovne vježbe, ritmičke vježbe, vježbe na spravama, štafetno trčanje, lakoatletsko natjecanje u skakanju i bacanju i rukometna utakmica. Slična produkcija priređena je 29. svibnja 1938. u suradnji s Franjevačkom klasičnom gimnazijom. ${ }^{141}$

Ostale Svačićeve sekcije u pojedinim godinama funkcionirale su s promjenjivim rezultatima. Od 1931./32. godine djelovala je šahovska sekcija. ${ }^{142}$ Svačićevi zainteresirani članovi su, uz čitanje knjiga i časopisa u prostoru čitaonice igrali šah. Da je za to postojalo veliko zanimanje, svjedoči povremeno priređivanje šahovskih turnira. Godine 1936./37. priređeni su jedan turnir i dvije simultanke, dok su tijekom 1937. i 1938. organizirani prijateljski ekipni susreti s gimnazijalcima iz koprivničkog Osvita ${ }^{143}$ Bio je to turnir na 8 ploča s neriješenim rezultatom. ${ }^{144}$ Filatelistička i slikarska sekcija tijekom pojedinih su godina također održa-

\footnotetext{
138 Godišnji izvještaj državne realne gimnazije u Varaždinu, Varaždin 1930., str. 11.

139 Varaždinska realna gimnazija 1931.- 32., Varaždin. 1932., str. 31.

140 Godišnji izvještaj državne realne gimnazije u Varaždinu, Varaždin 1933., str. 38.

141 Drž. realna gimnazija u Varaždinu, Godišnji izvještaj za školsku godinu 1936.- 37., str. 17 i 43.

142 Godišnji izvještaj državne realne gimnazije u Varaždinu, 1931.- 32., Đačka udruženja, str. 37.

143 Drž. realna gimnazija u Varaždinu, Godišnji izvještaj za školsku godinu 1936.- 37, str. 62.

144 Drž. realna gimnazija u Varaždinu, Godišnji izvještaj za školsku godinu 1937.- 38., str. 33.
} 
vale redovite tjedne sastanke. No, rad im je povremeno bio otežan jer Svačić nije imao svoju sobu.

Zbog obilježavanja 300-godišnjice Gimnazije društvo je 1936./37. godine počelo sustavno djelovati tek sredinom listopada, no zanimanje učenika za rad u Svačiću bilo je povećano, pa je udruženje poraslo na 400 članova. Godine 1938./39. rad društva i pojedinih sekcija vodili su profesori: Balić Martin, Horvat Ivo, Mimica Stjepan, Neimarević Ante i Borković Janko. ${ }^{145}$ No oblikovanjem Banovine Hrvatske djelovanje Gimnazijskog učeničkog društva Svačić, polako zamire. U gimnazijskim izvješćima ni u ostalim školskim dokumentima više nema spomena o njegovom radu, a lokalni tisak ne objavljuje ništa o njegovoj aktivnosti. Prema kasnijim izjavama pojedinih izrazito lijevo orijentiranih sudionika i u Svačiću su pred Drugi svjetski rat ideološki prevladali ljevičari pa je izmjenom političkog ozračja nakon Sporazuma Cvetković-Maček, društvu onemogućen daljnji rad. ${ }^{146}$

\section{ZAKLJUČAK}

Gimnazijsko učeničko društvo Svačić je jedna od omladinskih udruga nastalih tijekom liberalizacije političkog života nakon pada Khuenovog sustava. U slijedećih četvrt vijeka djelovalo je kao bitan čimbenik u oblikovanju glazbene i scenske aktivnosti u Gimnaziji, ali i u kulturno-zabavnom životu Varaždina. Pritom su kroz rad tamburaškog i pjevačkog zbora, među članstvom razvijane ljubav prema glazbi i vještine u njenoj interpretaciji. Ujedno su priređivanjem glazbeno-deklamatornih i scenskih produkcija, često popraćenih plesom, pribavljana sredstva kojima su se opremali i značajno pridonosili humanitarnoj aktivnosti, podupirući vlastite kolege, ali i siromašne u Varaždinu, posebno u ratnom i poratnom periodu.

Uvođenjem monarhističke diktature i ova je aktivnost uklopljena u nanovo organizirano Varaždinsko gimnazijsko udruženje Svačić pod čijim je okriljem režim pod strogim nadzorom okupio najveći dio učeničkih slobodnih aktivnosti u školi. Unutar društva pojedine su aktivnosti organizirane kroz sekcije čijim radom su rukovodili imenovani profesori, vodeći brigu o idejnom usmjeravanju aktivnosti prema duhu unitarizma i jugoslavenstva. lako je djelovanje čitavog društva bilo podvrgnuto nadzoru ravnatelja, pojedine su sekcije predvođene profesorima, uz neizbježno ispunjavanje režimskih zahtjeva, njegovale i nacionalne sadržaje, što je posebno dolazilo do izražaja na području glazbene i literarne aktivnosti. Osim u Gimnaziji, udruženje je i u ovom periodu ostavilo neizbrisiv trag u kulturno-zabavnom i društvenom životu Varaždina. 


\section{IZVORI I LITERATURA}

1/ Curicullum vitae, autobiografski rukopis profesora Miškulina u posjedu njegove kćerke Sonje Ranogajec.

2/ Krešimir FILIĆ: Glazbeni život Varaždina, Varaždin 1972. Gimnazija - SC «Gabriel Santo» Varaždin.

3/ Krešimir FILIĆ: "Povijest varaždinske gimnazije", Spomenica varaždinske gimnazije 1636. - 1936., Varaždin 1937.

4/ Milan ROGIĆ: 75 godina Šahovskog društva Varaždin, Varaždin 1982.

5/ Rudolf HORVAT: Povijest grada Varaždina, Varaždin 1993.

\section{SUMMARY}

\section{GYMNASIUM STUDENT ASSOCIATION SVAČIĆ}

Student association Svačić was founded in 1906 as a tamburitza orchestra operating within Varaždin Gymnasium and later it was converted into a tamburitza music association that held concerts outside school as well. Led by teacher Milan Stahuljak it consisted of a high-quality tamburitza orchestra and choir as well as a chamber orchestra. By summer 1913 they used to organize music and declamatory productions which were sometimes complemented with amateur shows and organized ballroom dances. Soon thereafter Svačić became one of the must-have participants of all the important events in Gymnasium, and their programs added new qualities to the cultural and entertainment offer in Varaždin. Before World War I teacher Tomislav Miškulin became their choirmaster and he put special emphasis on concert activities of the association. As soon as the political circumstances became more favorable (during and after the war) Svačić performances aided significantly in raising resources for the poor Gymnasium students and casualties of war.

As a consequence of the persistent work by Milan Kaman, the new head of Varaždin Gymansium, the dictatorial regime of the king Aleksandar eventually allowed the foundation of Varaždin Gymnasium association "Svačić“ in 1930 so that they may supervise extracurricular activities of the school. The activity of the association was defined by a rulebook („,Pravilnik“) which was approved by the Ministry of Education and it was set up through various sections. The first sections to be founded were the music, science, and literary sections, and in the 
upcoming years sports, visual arts, chess and philatelic sections were set up as well. The board of teachers appointed teachers who were leaders of particular sections which in turn held meetings where they elaborated programs for the so-called soirees. Those were events where sections presented their activities within the school or for the general population. Sometimes they even represented the school on a more formal level as well. A section that was especially prominent was the sports section which was led by teacher Zvonimir Suligoj. They were active both at local and state events. Music section, which was led by teacher Tomislav Miškulin, held concerts in the Croatian Music Association and Zagreb Cathedral. The literary section sometimes published students' works in Zagreb literary journals, and they published their own student journal called Svačić. With the help of their activities, social, culture and entertainment segment of Varaždin life in the 1930s was extremely rich and colorful. However, because of new political developments in the period leading up to World War II, this association ceased to exist.

Key Words: Students associations; Varaždin Gymnasium; choir; tamburitza orchestra; Varaždin. 